\title{
COVID-19 Vaccination in Patients With Multiple Sclerosis on Disease-Modifying Therapy
}

Andrew Wolf, MD, MS, and Enrique Alvarez, MD, PhD

Neurology: Clinical Practice August 2021 vol. 11 no. 4 358-361 doi:10.1212/CPJ.0000000000001088

Correspondence

Dr. Alvarez

enrique.alvarez@cuanschutz.edu

\begin{abstract}
The COVID-19 pandemic has resulted in challenges for the practice of neurology. One major concern is how to best manage patients with multiple sclerosis (MS) who are on disease-modifying therapies (DMTs). DMTs frequently have immunosuppressive properties that both increase the risk for COVID-19 and potentially reduce the immunologic response to vaccination in a group already vulnerable to infection due to neurologic deficits. Here, we review early data on COVID-19 outcomes in patients with MS and discuss what is known about vaccine effectiveness in those on anti-CD20 and sphingosine-1-phosphate receptor agents, which are proposed to have attenuating effects based on their mechanisms of action. In addition, we provide recommendations to best use novel COVID-19 vaccines in this population and highlight what information may better inform vaccine strategies in the future.
\end{abstract}

COVID-19 is a major public health challenge that has resulted in over 2 million deaths worldwide, in addition to extensive economic and social harms. Vaccination for the causative severe acute respiratory syndrome coronavirus 2 (SARS-CoV-2) virus has emerged as a critical mechanism to prevent COVID-19. In this context, there are unique considerations for patients with multiple sclerosis (MS), particularly those patients who are on immunosuppressive disease-modifying therapies (DMT) that may heighten risk for infection, worsen clinical outcomes from infection, and limit responsiveness to vaccines. Here, we discuss considerations for COVID-19 vaccination in patients with MS on DMT, as well as recommendations for vaccination planning in this vulnerable population.

\section{Discussion}

Patients with MS are at heightened risk of infections, particularly urinary and pulmonary infections. ${ }^{1}$ Furthermore, patients with MS are at heightened risk for severe infections (defined by hospitalization) than patients with other autoimmune conditions, which may reflect the contributions of neurologic deficits from MS (e.g., bladder dysfunction and dysphagia). ${ }^{2}$ Immunomodulatory DMTs, such as glatiramer acetate and interferons, do little to increase the risk beyond this baseline, as seen in their respective clinical trials and real world experience. ${ }^{3}$ However, immunosuppressive DMTs (particularly anti-CD20s) exacerbate the risk of infection. ${ }^{3}$ In the subpopulation treated with anti-CD20 DMT, male sex and time on rituximab increase the infection risk, but higher disability is a key factor. ${ }^{4}$ Although knowledge is evolving, these risks appear to extend to COVID-19. Risk for severe COVID-19 in the MuSC- 
19 registry (defined as pneumonia, hospitalization, or death) was higher for those patients with MS using anti-CD20 DMT. ${ }^{5}$ Older age, longer disease course, higher disability, progressive disease, and the presence of comorbidities were also associated with severe COVID-19 infection. Preliminary data from the MS Global Data Sharing Initiative also suggested that use of anti-CD20 drugs is associated with $1.5 \times$ more hospitalizations, $2.5 \times$ more intensive care admissions, and $3 \times$ more use of mechanical ventilation compared with other DMTs (Simpson ECTRIMS 2020). However, the COVISEP registry data did not show an association between COVID-19 outcomes and DMT. ${ }^{6}$ Taken together, this suggests that patients with MS, especially in certain groups, may be at increased risk for infection and for poor outcomes, further emphasizing the need for effective vaccination.

Dozens of COVID-19 vaccines are in clinical use or development worldwide; 2 vaccines are currently being administered in the United States under emergency use authorization granted by the FDA. These vaccines, BNT162b2 (Pfizer, New York, NY, and BioNTech, Mainz, Germany) and messenger RNA (mRNA)-1273 (Moderna, Cambridge, MA), use lipid nanoparticle-encapsulated mRNA to encode S-2P antigen (modified prefusion conformation of the full-length spike protein). ${ }^{7}$ The spike protein is critical for cellular entry of SARS-CoV-2, and these vaccines have demonstrated about $95 \%$ protection against symptomatic COVID-19 infection over a 2-month period. ${ }^{8,9}$ Additional candidates are in phase 3 trials in the United States; some of the other vaccines (notably OxfordAstraZeneca approved in the United Kingdom) use a novel nonreplicating adenovirus vector. DMTs may affect the immunologic responsiveness to any vaccination because they treat MS by modulating/suppressing the immune system. That said, the extent to which any specific DMT may have an impact on COVID-19 vaccine responsiveness is not known. Current data on the efficacy of vaccines in patients with MS on immunosuppressive DMT are limited to traditional vaccine platforms and not the novel mRNA or adenovirus platforms at the forefront of the COVID-19 vaccine programs. With this limitation, there are reasonable concerns about how effective any of the COVID-19 vaccines may be in patients with MS on DMTs.

A full review of vaccines in patients with MS is beyond our scope $\left(\right.$ Ciotti et al. $\left.{ }^{10}\right)$. However, completed vaccine studies provide insights regarding if DMTs may affect the efficacy of COVID-19 vaccines. COVID-19 infection induces response in the innate immune system and the adaptive immune system (i.e., antigenspecific cytotoxic $T$ cells directed against the virus and adaptive B-cell response with ultimate production of novel antibodies). Higher ratios of IgG antibodies targeting S1 or receptor-binding domains of the spike protein compared with the nucleocapsid protein were associated with milder illness indicating potential importance for specific antibodies; however, the overall antibody response was considered insufficient to predict clinical outcome. ${ }^{11}$ Notably, patients with X-linked hypogammaglobulinemia, in addition to most patients with iatrogenic B-cell depletion, can recover from COVID-19 infection, indicating that although $\mathrm{B}$ cells may be important in the response to infection, they are not strictly necessary for recovery. ${ }^{5,6,12}$ There is activation of virus-specific $\mathrm{CD} 4^{+}$and $\mathrm{CD} 8^{+} \mathrm{T}$ cells in response to BNT162b1, indicating that at least with mRNAbased vaccines, the protective response may be multifactorial. ${ }^{13}$

The potential for B cell-depleting therapies to attenuate vaccine response is a concern due to their direct effect on humoral immunity and the role of $\mathrm{B}$ cells in antigen presentation. This is concordant with concerns about serologic conversion following COVID-19 infection. We are aware of 9 cases of patients with MS who were on anti-CD20 DMT with documented COVID-19 by PCR, but negative serologic testing. ${ }^{14-17}$ That said, the portion of patients, if any, who do seroconvert from infection is not known, and how any degree of baseline hypogammaglobulinemia affects this process is similarly uncertain. Broadly, the recent VELOCE trial demonstrated reduced levels of vaccine (tetanus toxoid, pneumococcal 13, and influenza) responsiveness and protection, as well as impaired humoral response to stimulatory antigen keyhole limpet hemocyanin, in patients with MS on ocrelizumab. ${ }^{18}$ There are no specific data on vaccine responsiveness in patients with MS on rituximab or ofatumumab; the literature from rheumatoid arthritis suggests that rituximab decreases responsiveness similarly. ${ }^{19}$

The other class of medications concerning for impairing vaccine responsiveness is sphingosine-1-phosphate receptor modulators, which suppress lymphocyte egress from lymph nodes. In a placebo-controlled trial, patients on fingolimod were significantly less likely to respond to influenza and tetanus toxoid vaccines, although the majority still did mount an appropriate response. ${ }^{20}$ An additional study evaluating response to influenza vaccination in patients on fingolimod demonstrated reduced response rates when compared with patients not on DMT, in addition to those on glatiramer acetate or interferon beta (neither of which was different from control). ${ }^{21}$ Like B celldepleting therapies, fingolimod may prevent seroconversion. ${ }^{22}$ There are limited data on siponimod with 1 placebo-controlled study demonstrating reduced responsiveness to vaccination and no published data on ozanimod. ${ }^{23}$

\section{Conclusions}

Widely available and effective vaccination for COVID-19 is an exciting prospect. Although the first FDA-authorized vaccines were given December 2020, the logistics of administration remain challenging. Widespread vaccination may not occur until late 2021. This poses critical questions for patients on or considering initiation of DMT.

For stable patients, continuing current DMT is recommended. Although there is concern that outcomes may be worse and that vaccination may be less effective while on some DMTs, stopping or switching DMT leads to 
considerable logistical challenges and may lead to rebound disease activity (e.g., for fingolimod). As there are data that the therapeutic effects of rituximab can extend for months beyond the timing of humoral immune reconstitution, it may be possible to extend the dosing interval to create a window to administer the COVD-19 vaccine and allow for immunologic response. ${ }^{24}$ To maximize the immunologic response, it is suggested by the Canadian Network of MS Clinics (cnmsc.ca/Covid19VaccineGuidance) to wait 4 weeks after the 2nd mRNA vaccine dose for new or repeat infusion of anti-CD20 DMT. For patients already on anti-CD20 DMT, waiting 12 weeks (as in the VELOCE study) after infusion to start the vaccination process is recommended. It has also been proposed to delay vaccination until B-cell reconstitution or toward the end of an infusion cycle, but the risks of contracting COVID-19 need to be considered.

For patients who have not started DMT, considerations for DMT include the expected impact on vaccine efficacy and what other treatment options are available to control the patient's MS. If possible, a DMT start could be delayed. The prescribing information for ocrelizumab recommends that if possible, to vaccinate with nonlive vaccines 2 weeks before initiation of treatment (Genentech 2017). As above, it is reasonable to extend this interval to 4 weeks following the second dose of a COVID-19 mRNA vaccine. In addition, a bridging strategy could be used by temporarily choosing another DMT. Natalizumab (expected to have minimal impact on COVID-19 vaccine efficacy) is an alternative and could be used in the short-term, even in patients who are JC virus positive. Glatiramer acetate, interferon beta, and dimethyl fumarate are predicted to have relatively minimal impact on COVID-19 vaccination responsiveness and may be more frequently used.

Further characterizing specific vaccine responses with antibody titers and $\mathrm{T}$-cell responses in patients on specific DMTs, in addition to clinical outcome data, will be useful in guiding how to treat and vaccinate patients with MS during the COVID-19 pandemic and into the future. It is recommended that despite uncertainty about vaccination effectiveness, all patients with MS without other contraindications receive a COVID-19 vaccine and follow the AAN vaccine guidelines. ${ }^{25}$ Long-term, more knowledge is needed about the factors that increase infection rates and how to mitigate them when possible. A comprehensive strategy around choosing how and when (or not) to treat patients with DMTs as well as developing a vaccination strategy for COVID-19 and other preventable infections in patients with MS is worthy of further investigation.

\section{Study Funding}

No targeted funding reported.

\section{Disclosure}

A. Wolf reports no disclosures relevant to the manuscript. E. Alvarez has consulted with Actelion/Janssen, Alexion, Bayer,
Biogen, Celgene/BMS, EMD Serono/Merck, Genentech/ Roche, Genzyme, Novartis, Sanofi, and TG Therapeutics and research support from Biogen, Genentech/Roche, Novartis, TG Therapeutics, Patient-Centered Outcomes Research Initiative, National Multiple Sclerosis Society, NIH, and Rocky Mountain MS Center. Full disclosure form information provided by the authors is available with the full text of this article at Neurology.org/cp.

\section{Publication History}

Received by Neurology: Clinical Practice January 25, 2021. Accepted in final form March 18, 2021.

Appendix Authors

\begin{tabular}{|c|c|c|}
\hline Name & Location & Contribution \\
\hline $\begin{array}{l}\text { Andrew Wolf, } \\
\text { MD, MS }\end{array}$ & $\begin{array}{l}\text { Department of Neurology, } \\
\text { University of Colorado } \\
\text { School of Medicine, Aurora }\end{array}$ & $\begin{array}{l}\text { Drafting/revision of the } \\
\text { manuscript for content, } \\
\text { including medical writing } \\
\text { for content; major role in } \\
\text { the acquisition of data; } \\
\text { study concept or design; } \\
\text { and analysis or } \\
\text { interpretation of data }\end{array}$ \\
\hline $\begin{array}{l}\text { Enrique } \\
\text { Alvarez, MD, } \\
\text { PhD }\end{array}$ & $\begin{array}{l}\text { Department of Neurology, } \\
\text { University of Colorado } \\
\text { School of Medicine, Aurora }\end{array}$ & $\begin{array}{l}\text { Drafting/revision of the } \\
\text { manuscript for content, } \\
\text { including medical writing } \\
\text { for content; major role in } \\
\text { the acquisition of data; } \\
\text { study concept or design; } \\
\text { and analysis or } \\
\text { interpretation of data }\end{array}$ \\
\hline
\end{tabular}

\section{References}

1. Persson R, Lee S, Ulcickas Yood M, et al. Infections in patients diagnosed with multiple sclerosis: a multi-database study. Mult Scler Relat Disord. 2020;41: 101982.

2. Montgomery S, Hillert J, Bahmanyar S. Hospital admission due to infections in multiple sclerosis patients. Eur J Neurol. 2013;20:1153-1160.

3. Luna G, Alping P, Burman J, et al. Infection risks among patients with multiple sclerosis treated with fingolimod, natalizumab, rituximab, and injectable therapies. JAMA Neurol. 2020;77(2):184-191.

4. Vollmer BL, Wallach AI, Corboy JR, Dubovskaya K, Alvarez E, Kister I. Serious safety events in rituximab-treated multiple sclerosis and related disorders. Ann Clin Transl Neurol. 2020;7:1477-1487.

5. Sormani MP, De Rossi N, Schiavetti I, et al. Disease modifying therapies and Covid19 severity in multiple sclerosis. Ann Neurol. 2021;89:780-789.

6. Louapre C, Collongues N, Stankoff B, et al. Clinical characteristics and outcomes in patients with Coronavirus disease 2019 and multiple sclerosis. JAMA Neurol. 2020;77(9): 1079-1088.

7. Dai L, Gao GF. Viral targets for vaccines against COVID-19. Nat Rev Immunol. 2021; 21(2):73-82.

8. Baden LR, El Sahly HM, Essink B, et al. Efficacy and safety of the mRNA-1273 SARS CoV-2 vaccine. $N$ Engl J Med. 2021;384(5):403-416.

9. Polack FP, Thomas SJ, Kitchin N, et al. Safety and efficacy of the BNT162b2 mRNA Covid-19 vaccine. N Engl J Med. 2020;383(27):2603-2615.

10. Ciotti JR, Valtcheva MV, Cross AH. Effects of MS disease-modifying therapies on responses to vaccinations: a review. Mult Scler Relat Disord. 2020;45:102439.

11. Roltgen K, Powell AE, Wirz OF, et al. Defining the features and duration of antibody responses to SARS-CoV-2 infection associated with disease severity and outcome. Sci Immunol. 2020;5(54):eabe0240.

12. Quinti I, Lougaris V, Milito C, et al. A possible role for B cells in COVID-19? Lesson from patients with agammaglobulinemia. J Allergy Clin Immunol. 2020;146(1):211-213.e4.

13. Sahin U, Muik A, Derhovanessian E, et al. COVID-19 vaccine BNT162b1 elicits human antibody and TH1 T cell responses. Nature. 2020;586:594-599.

14. Conte WL. Attenuation of antibody response to SARS-CoV-2 in a patient on ocrelizumab with hypogammaglobulinemia. Mult Scler Relat Disord. 2020;44:102315.

15. Meca-Lallana V, Aguirre C, Beatrizdel R, Cardenoso L, Alarcon T, Vivancos J. COVID-19 in 7 multiple sclerosis patients in treatment with ANTI-CD20 therapies. Mult Scler Relat Disord. 2020;44:102306.

16. Thornton JR, Harel A. Negative SARS-CoV-2 antibody testing following COVID19 infection in two MS patients treated with ocrelizumab. Mult Scler Relat Disord. 2020;44:102341. 
17. Maillart E, Papeix C, Lubetzki C, Roux T, Pourcher V, Louapre C. Beyond COVID19: DO MS/NMO-SD patients treated with anti-CD20 therapies develop SARS CoV2 antibodies? Mult Scler Relat Disord. 2020;46:102482.

18. Bar-Or A, Calkwood JC, Chognot C, et al. Effect of ocrelizumab on vaccine responses in patients with multiple sclerosis: the VELOCE study. Neurology. 2020;95: e1999-e2008.

19. Bingham CO III, Looney RJ, Deodhar A, et al. Immunization responses in rheumatoid arthritis patients treated with rituximab: results from a controlled clinical trial. Arthritis Rheum. 2010;62:64-74.

20. Kappos L, Mehling M, Arroyo R, et al. Randomized trial of vaccination in fingolimodtreated patients with multiple sclerosis. Neurology. 2015;84:872-879.

21. Olberg HK, Eide GE, Cox RJ, et al. Antibody response to seasonal influenza vaccination in patients with multiple sclerosis receiving immunomodulatory therapy. Eur J Neurol. 2018; 25:527-534.
22. Bollo L, Guerra T, Bavaro DF, et al. Seroconversion and indolent course of COVID 19 in patients with multiple sclerosis treated with fingolimod and teriflunomide. J Neurol Sci. 2020;416:117011.

23. Ufer M, Shakeri-Nejad K, Gardin A, et al. Impact of siponimod on vaccination response in a randomized, placebo-controlled study. Neurol Neuroimmunol Neuroinflamm. 2017;4(6):e398.

24. Maarouf A, Rico A, Boutiere C, et al. Extending rituximab dosing intervals in patients with MS during the COVID-19 pandemic and beyond? Neurol Neuroimmunol Neuroinflamm. 2020;7(5):e825.

25. Farez MF, Correale J, Armstrong MJ, et al. Practice guideline update summary: vaccine-preventable infections and immunization in multiple sclerosis: report of the guideline development, dissemination, and implementation Subcommittee of the American Academy of Neurology. Neurology. 2019;93: 584-594.

\section{Share Your Insights, Expertise, and Experiences}

- How are you employing drugs and devices in your field?

- What ethical challenges do you face?

- Do you have a case report that is illustrative of a clinical challenge?

- What challenges have you faced or successes have you enjoyed in bringing greater efficiency to your practice?

Deliver a high-quality, peer-reviewed message to your colleagues in practice, submit your paper at NPub.org/NCP/submit. 


\section{Neurology ${ }^{\circ}$ Clinical Practice}

\section{COVID-19 Vaccination in Patients With Multiple Sclerosis on Disease-Modifying Therapy \\ Andrew Wolf and Enrique Alvarez}

Neurol Clin Pract 2021;11;358-361 Published Online before print April 14, 2021
DOI 10.1212/CPJ.0000000000001088

This information is current as of April 14, 2021

Updated Information \&
Services

References

Citations

Subspecialty Collections

Permissions \& Licensing

Reprints including high resolution figures, can be found at:

http://cp.neurology.org/content/11/4/358.full.html

This article cites 25 articles, 6 of which you can access for free at: http://cp.neurology.org/content/11/4/358.full.html\#\#ref-list-1

This article has been cited by 2 HighWire-hosted articles: http://cp.neurology.org/content/11/4/358.full.html\#\#otherarticles

This article, along with others on similar topics, appears in the following collection(s):

All Clinical Neurology

http://cp.neurology.org//cgi/collection/all_clinical_neurology

All Demyelinating disease (CNS)

http://cp.neurology.org//cgi/collection/all_demyelinating_disease_cns

All Immunology

http://cp.neurology.org//cgi/collection/all_immunology

All Infections

http://cp.neurology.org//cgi/collection/all_infections

COVID-19

http://cp.neurology.org//cgi/collection/covid_19

Multiple sclerosis

http://cp.neurology.org//cgi/collection/multiple_sclerosis

Information about reproducing this article in parts (figures,tables) or in its entirety can be found online at:

http://cp.neurology.org/misc/about.xhtml\#permissions

Information about ordering reprints can be found online:

http://cp.neurology.org/misc/addir.xhtml\#reprintsus

Neurol Clin Pract is an official journal of the American Academy of Neurology. Published continuously

since 2011, it is now a bimonthly with 6 issues per year. Copyright Copyright @ 2021 American Academy of Neurology. All rights reserved. Print ISSN: 2163-0402. Online ISSN: 2163-0933.

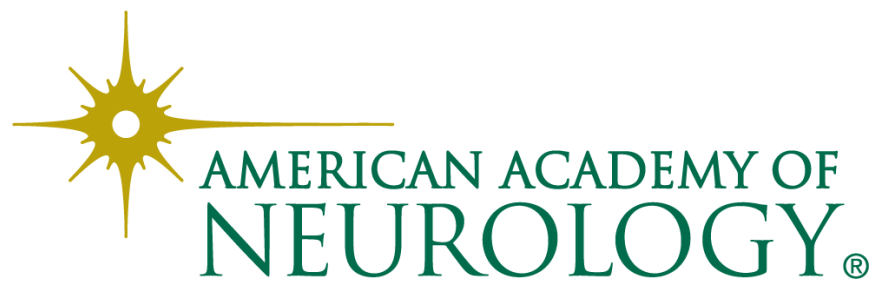

